\title{
Features of social policy in modern Russia
}

\begin{abstract}
Annotation
Based on extensive factual material, radical contradictions between the content of official goals of social policy and the realities of life of citizens of modern Russia are considered. The author sees the reasons for this situation primarily in the professional unfitness of the authorities and the "market" model that underlies the functioning of the state. Directions and specific mechanisms for overcoming the problems are proposed.
\end{abstract}

Keywords: social policy, social sphere, market, human potential

\author{
Volume 4 Issue 6 - 2020
}

\author{
E.PTavokin \\ Professor of the Russian technological University, Russia
}

Correspondence: EP Tavokin, Doctor of social Sciences, Professor of the Russian technological University, Russia, Email tavkin@mail.ru

Received: October 13, 2020 | Published: December 24, 2020

\section{Introduction}

Social policy plays a huge role in the functioning of any state, since problems that arise in the social sphere directly affect the state and functioning of the country's economic and political processes, and the life of every person.

Social policy is an integral part of the overall strategy of the state related to the social sphere. It is a purposeful activity aimed at developing and implementing decisions directly related to a person and his / her position in society and is aimed at ensuring conditions for full-fledged human activity, improving the General level of wellbeing of the population and creating an effective system of social guarantees, taking into account the capabilities of society and the characteristics of various groups of the country's population. Social policy, if properly organized, ensures that social needs are met and social development goals are achieved to the best of its ability. ${ }^{1,2}$

Having the social sphere as its object, social policy ultimately determines the quality of life of people, their social mood, that is, the parameters of human potential that affect the state of other important spheres of society - economic and political. The social sphere reflects the degree of humanity of the state's policy. Finally, without an effective social policy, it is impossible to develop creativity in human activity as the main element of the productive forces of social and economic development.

If we proceed from the essence, principles and goals of social policy, then in the most General approach, the functions of social policy are to ensure sustainable socio-economic development (1), social rights (2), social security (3), social protection (4), and reduce the level of social tension (5). Let's look at how these functions are implemented and how this affects the state of human potential.

The concept of "sustainable development" became widespread after the publication of a report prepared for the UN in 1987. International Commission on environment and development. This concept is based on the need to maintain a balance between solving social and economic problems, on the one hand, and preserving the environment, on the other. In June 1992, the UN conference on environment and development (UNCED) was held in Rio de Janeiro, where a historic decision was made to change the course of development of the entire world community. This unprecedented decision by the heads of government and leaders of 179 countries gathered at UNCED was due to the rapidly deteriorating global environmental situation and the global catastrophe predicted on the basis of an analysis of its dynamics, which could break out in the twenty-first century and lead to the death of all life on the planet. Russia, which signed the documents of the above-mentioned UN conference, has made serious commitments to implement the program of global cooperation adopted by consensus.

In Russia, in February 1994, the President signed a decree on the transition of the Russian Federation to a model of sustainable development. $^{3}$ The concept of transition to sustainable development in Russia was adopted in 1996. It provided for the implementation of a set of measures aimed at preserving human life and health, solving the demographic problem, fighting crime, eradicating poverty, changing the structure of consumption and reducing the level of socio-economic stratification of the population. The main indicators of quality of life were identified as criteria for sustainable development: human life expectancy (expected at birth and actual), health status, environmental deviation from standards, level of knowledge and educational skills, income measured by gross domestic product per capita, employment level, and the degree of realization of human rights.

The results of the implementation of this concept by the monetarist liberals in power in our country are extremely bright and revealing. In the shortest possible way, they look like this.

Russia ranked 117th out of 170 countries in terms of economic growth in 2018. From the G20 countries - in all respects the 20th place. According to the corruption perception index in 2018, it ranked 136th out of 180 countries, far ahead of Moldova (116), Ukraine (120) and Kazakhstan (123). As of 2017, 18 million Russian citizens periodically use drugs. At the same time, $60 \%$ of drug addicts are people from 16 to 30 years old, and $20 \%$ are schoolchildren. $20 \%$ of the world's heroin addicts live in Russia. During the years of "reforms", the country lost approximately 23 million indigenous people, and including the unborn and missing (listed as alive) - more than 42 million. The destruction of free education and health care systems and the collapse of advanced industries and agriculture are almost complete. Pedophilia and the slave trade flourish. As a result, if the USSR in 1989 ranked 26th in the world in terms of the human potential index (HPI), behind the United States with its 19th place only 7 positions, this gap has increased many times today. So, according to the results of 2018 Russia, which has become a "market", capitalist and "democratic" country, is only 49th in the world PPI rating, while the United States is 15 th. The list of "achievements" can be continued. At the same time, it should be noted that such "black stuff" is not at all "myths of dogmatic Communists", but UN reference books. ${ }^{4}$ Liberal theorists do not pay any attention to all this, continuing to terrorize the public consciousness with the "horrors of Soviet totalitarianism". These are the "successes" of the Russian Federation in terms of sustainable socio-economic development. 
What is the situation with ensuring social rights in the Russian Federation?

Social human and civil rights are defined in a variety of international documents: acts, proclamations, declarations, codes, conventions, etc. the most important of them are international documents of a universal nature: the international bill of human rights, the Declaration of social progress and development, the International labour organization conventions, the Convention for the protection of human rights and fundamental freedoms and its protocols, the Commonwealth of Independent States Convention on human rights and fundamental freedoms, etc.

In modern Russia, human and civil rights and freedoms are recognized and guaranteed at the legislative level in accordance with the generally recognized principles and norms of international law in accordance with the Constitution of the Russian Federation. ${ }^{5}$ Russian citizens have the right to:

1. Freely dispose of their abilities to work, choose their occupation and profession.

2. To work in conditions that meet the requirements of safety and hygiene, to remuneration for work without discrimination and not lower than the minimum wage established by Federal law, to protection from unemployment.

3. Individual and collective labor disputes using the methods established by Federal law to resolve them, including the right to strike.

4. On vacation, for the duration of working hours guaranteed by law, weekends and holidays, paid leave.

5. Taking care of children and their upbringing is an equal right and duty of parents.
6. Social security for age, illness, disability, loss of breadwinner, and child rearing.

7. On housing. No one may be arbitrarily deprived of their home. For the poor ... it is provided free of charge or for an affordable fee from state, municipal and other housing funds in accordance with established standards.

8. For health protection and medical care. Medical care in state and municipal health care institutions is provided to citizens free of charge.

9. On education. Pre-school, basic General and secondary vocational education in state or municipal educational institutions and enterprises are guaranteed to be accessible to all and free of charge. Everyone has the right to obtain higher education free of charge at a state or municipal educational institution and at an enterprise on a competitive basis.

10. To participate in cultural life and use cultural institutions, and to have access to cultural property.

These rights and freedoms must be ensured by the activities of the legislative and Executive authorities, local self-government and justice. The attractiveness and distinct social orientation of the constitutionally guaranteed rights of citizens are in blatant dissonance with the depressing state of the current Russian state. The scale of dissonance excludes the possibility of considering any accidents as the cause of this phenomenon. It is obvious that this reason is systemic and consistently non-random.

To identify the causes of the problem, we will consider some of the social rights of a person and citizen enshrined in the Constitution of the Russian Federation, and the nature of their implementation, they are shown in the Table 1.

Table I Rights under consideration

The rights Nature of implementation

Due to the almost complete destruction of the productive, high-tech sphere of the economy, science and other industries, promising (i.e. paid) professions in the labor market are concentrated in a vanishingly narrow range: lawyers, financiers, managers, officials, and some medical specialties.

Freely dispose of their abilities to work, choose the type of activity and profession.

Taking care of children and raising them is an equal right and duty of parents.

For health protection and medical care. Medical care in state and municipal health care institutions is provided to citizens free of charge ... Competition in these professions is extremely high, and few people can reveal their "ability to work" in them. For truly creative young people who have shown themselves in science (mathematics, physics, biology, etc.), engineering, and technology, effective mechanisms for their employment in the West have been created. As a result, over the years of "reforms" in science and high-tech industries, more than $70 \%$ of the best specialists were lost. The damage to Russia is estimated at about $\$ 2$ trillion. Most of the remaining people are forced to find jobs outside their specialty and "dispose of their abilities to work" in such an unnatural way.

In modern Russia, the share of children born in unregistered marriages is $30 \%$. The share of orphans with living parents is $90 \%$. The share of abortions among minors out of the total number of abortions is $10 \%$. Before the "reforms", mothers rarely refused to give birth to children, but in the 1990s, cases of refusal became more frequent and widespread, and in the 2000s they took on the character of an epidemic. The number of annual refusals from children is $10-1 \mathrm{I}$ thousand. On average, there are about five rejections per maternity hospital per year. And about $11 \%$ of women immediately after giving birth ran away from the hospital, leaving their children and leaving no information about themselves. Russia ranks Ist in the world in the number of children abandoned by their parents. According to various estimates, there are from 2 to 5 million street children in the Russian Federation.

On a per capita basis, Russia spends 17 times less on health care than in Europe and about 75 times less than in the United States. In 2020, Russia ranked I24th in the world in terms of GDP per capita, next to Dominica and Saint Lucia. In terms of life expectancy, the Russian Federation ranked 104th in the world, significantly behind Belarus, Ukraine, Armenia and other former Soviet republics. In Russia, which is shaking all the world's leading demographers and sociologists at a catastrophic rate of its extinction, healthcare spending has been steadily declining since 2016 . According to The Herzen Institute, the incidence of malignant neoplasms (cancer) increased by $25 \%$ in the ten years from 2008 to 2018 . 


\begin{tabular}{|c|c|}
\hline The rights & Nature of implementation \\
\hline $\begin{array}{l}\text { On education. Pre-school, basic General } \\
\text { and secondary vocational education are } \\
\text { guaranteed to be accessible and free } \\
\text { of charge .... Everyone has the right to } \\
\text { receive higher education free of charge } \\
\text { on a competitive basis ... }\end{array}$ & $\begin{array}{l}\text { From } 201 \text { I to } 2018 \text {, the share of paid education in Russian universities increased from } 25 \% \text { to } \\
40 \% \text {. By } 2024 \text {, it is planned to increase by another } 17 \% \text {. Thus, in the total number of students, the } \\
\text { ratio of paid and budget places is almost equal. However, in the most prestigious universities, the } \\
\text { share of budget places does not exceed } 5-10 \% \text {. At the same time, if the average cost of training } \\
\text { in the Russian Federation is } 140 \text { thousand rubles, then in "prestigious" universities it has already } \\
\text { exceeded one million per year. The cost of "educational services" in higher education institutions } \\
\text { on average increases by I5\% per year. }\end{array}$ \\
\hline $\begin{array}{l}\text { To participate in cultural life and use } \\
\text { cultural institutions, and to have access } \\
\text { to cultural property. }\end{array}$ & $\begin{array}{l}\text { According to the FOM, no more than } 16 \% \text { of the population visit museums, exhibitions, theaters, } \\
\text { and concert halls at least once every } 2-3 \text { years, } 11 \% \text { visit the library and reading room, and } 3 \% \\
\text { attend clubs and clubs of interest. }\end{array}$ \\
\hline
\end{tabular}

As you can see, the rights under consideration are implemented in very strange, specific forms and on an extremely limited scale. The situation is no better with other social rights. This situation is largely explained by the fact that currently $85-90 \%$ of the country's population lives from paycheck to paycheck. There is a clear tendency for the situation to worsen. According to Rosstat, due to the fall in production, real incomes of the population are steadily declining. At the beginning of 2020, about 21 million Russian citizens live below the poverty line. According to unofficial data, their number is at least 2 times more. The population's debt burden is growing from year to year. More than a quarter $(26 \%)$ of children under the age of 18 live in families with incomes below the subsistence level, creating a "poverty trap". If you clear the essence of the "reforms" of education and health care from the verbal husk, they are reduced to their transformation (in violation of the Constitution!) of state obligations in the sphere of paid services. This is the case with the rights of Russian citizens and the nature of their implementation.

One of the most important functions of social policy is to ensure social security, the meaning of which is to enable individuals, social groups, communities, and society to meet social needs and interests. The result of its effective implementation should be a state of protection of vital social interests of the individual, the state, and society from social dangers. Sources of social hazards can be internal or external. Internal sources include: unfair distribution of property, income, life goods, and power; the existence of an antagonistic social structure that professes diametrically opposite, irreconcilable interests and goals. External threats to social security are caused by the deterioration of the global social situation. Its main forms include: the expansion of the zone of poverty, the aggravation of the food problem, the spread of hunger, diseases, epidemics, drug addiction, crime and social injustice.

The implementation of the social security function takes place in a very characteristic form. Both internal and external sources of social dangers in modern Russia function extremely effectively. Suffice it to recall the first stage of "shock therapy", when the entire country was robbed at once, and the second stage - "voucher privatization", as a result of which almost all the public property was in the hands of a bunch of scammers. As one of the next stages of the robbery of citizens of the Russian Federation, we can consider the pension "reform" of 2019, according to which every potential pensioner is robbed by the state for one million at the lowest possible estimates. The gradual robbery of the country and the population continues in the form of continuous increases in taxes, tariffs, prices, fines, etc., while "antagonistic social structures" flourish and find full approval and support in the corridors of power. As for external threats, the maniacal commitment of the highest authorities to the strategy of satisfying any claims of the so-called "civilized" countries, even under the most humiliating conditions, means that Russia is open to almost all of the above-mentioned external threats.

Social protection is also one of the most important functions of social policy. The basic guarantees of social protection are established in the Constitution of the Russian Federation [2, Article 7]. It guarantees the protection of labor and health of people, the minimum wage, state support for the family, motherhood, fatherhood and childhood, the disabled and elderly citizens, the development of the social services system, state pensions and benefits, and social security for age, in case of illness, disability, or loss of a breadwinner.

There are two widely accepted points of view in the literature on understanding the meaning of social protection. According to the first (the most popular), social protection has as its object the disabled (mainly pensioners) and low-income people, socially vulnerable groups (young workers and specialists, etc.) [3, P. 49]. ${ }^{6}$ The second (broad) point of view interprets social protection as the protection of a person from the negative effects of the environment as a whole. In accordance with the compromise point of view, devoid of the extremes of the first two, social protection is the protection of a person from adverse factors of the social environment. The purpose of social protection is to mitigate the consequences of such impacts and minimize social risks. At the same time, social risk is understood as a possible event in which a person permanently or temporarily loses the ability to work, or the demand for their work. Social risk factors may include loss of the ability to work as a result of illness, an accident at the place of work, or lack of demand for work in the event of unemployment. The consequence of the implementation of social risk is the loss of income, material insecurity, and the need to receive medical care.

One of the fundamental conditions for the effectiveness of social protection is strict adherence to the principle of universality of social policy. According to it, the amount of social security aimed at social protection should solve the main task - ensuring a minimum subsistence level for the entire population. The remaining part of the company's income should be differentiated depending on the labor contribution and the size of the property. Modern Russia, as follows from the previous presentation, is still far from this ideal, and the need to achieve it is the most important strategic task.

If all the functions of social policy discussed above were successfully implemented, another important function of social policy would be to reduce social tension. Social tension refers to a state of social situation, the manifestation of which is the dissatisfaction and discontent of a significant part of the population with the existing order of functioning of society, the aggravation of contradictions, 
and the instability of important processes. The fundamental cause of social tension is the contradiction between the needs, interests, and expectations of large social communities and groups, and the unsatisfactory level or quality of their satisfaction, unfair restrictions on access to resources, and mass dissatisfaction with the quality of life. Social tension arises when a significant part of social groups, communities, strata clearly realize that they do not have the opportunity in the present and in the near future to meet their immediate needs and achieve important, first of all, the most basic life goals.

Social tension manifests itself in public opinion and mass protest actions. Traditional indicators for assessing social tension are the level of trust in the authorities (state and municipal) and the level of protest moods. According to estimates of the sociological service "Public opinion Foundation" during 2019-2020, the share of citizens of the Russian Federation who had to hear from people around them critical statements about the Russian authorities, steadily held about $62 \%-65 \%$. This means that social tension in modern Russian society has reached its extreme limits. According to the Levada center at the beginning of 2020, every fourth Russian citizen is ready to take part in mass protests. And this is not surprising! The total underinvestment of the socio-economic sphere of our country (which is not only the real sector, but also housing and utilities, education, health, science, etc.) is $85 \%$. Russia has almost lost all opportunities for independent movement into the future. And social and regional differentiation has reached such a level that simply preserving the state unity of the Russian Federation looks extremely difficult and less and less solvable.

The main reasons for failures in the economy and social sphere, among other things, should be sought, first of all, in the professional unpreparedness and lack of the necessary moral qualities of those who, for some misunderstanding, are called "elite". The ritual approach to the economy based on standard and, as it turned out, speculative schemes developed exclusively for "external" use, proposed by the West, and zealously performed with schoolboy pedantry by the "elite", destroyed almost all (except for raw materials) spheres of life in Russia.

To survive, Russia needs to stop imitating Western standards of life and start living in its own way, truly, with pleasure, with courage. And, above all, we must stop praying for the "sacred cow" of liberalism's economy, which is by no means a fate, as the liberal hoaxers assure us, but rather a curse. The time is not far off when calling yourself a liberal will be tantamount to admitting utter stupidity, inexcusable for an educated person, deep ignorance. With "market" experiments, it's time to stop: either Russia will bury the "market", or the "market" will bury Russia. The third is not given! There are three main obligations of the state to its citizens: to teach, to treat, and to protect. This is the basis of the social contract. And they cannot be a "service sector", a market commodity, if, of course, the state intends to develop and build prospects for the future.

History has repeatedly proved that the most effective society is one that acts in solidarity, synchronously, together, and is not torn apart by the "struggle" for existence. People should be in the so-called "valence" state, that is, they should be ready to solve big, inspiring tasks, they should feel that they are accomplices in achieving grandiose, inspiring goals that they perceive as their own, personal. Only in this case, significant social transformations are possible.

The level of development of modern productive forces is such that it will not be difficult to organize national economy in such a way that everyone's labor will be fully and best used, and all the needs of each member of society will be equally satisfied. This is not even a political economic task. This is a purely technical task of balancing opportunities and socially justified strategic needs. This is a matter for industry specialists, analytical scientists, mathematicians, engineers, programmers, but not for "economists", financiers, parodists, "couturiers", ballerinas, film Directors and other cellists with double bass players.

The "invisible hand of the market" is only good for easing the pockets of gullible simpletons. Creation requires visible, tangible, strong hands, guided not by the self-serving will of a thief, but by the mind of a human Creator, a human sage who has realized the laws of social development, who constructs being in strict accordance with a scientifically based project, in the interests of the whole society, but not a handful of social parasites. This should be the subject of a new social policy.

The fundamental functions of this new social policy include:

- formation of a rational structure of income and needs of society;

- stimulating the motivational principles of activating the labor productive activity of employees;

- coordination of personal, collective and public interests;

- accounting for each employee's share in the creation and distribution of public goods;

- development of the social infrastructure of the society.

Formation of rational structure of earnings and the needs of society involves the development of society for a certain, sufficiently long period of time; creating a targeted integrated programs aimed at its implementation; defining the scope and structure of needs of the society for a specified period in order to lay them in the options for the development of production. Thus, a full-fledged social policy determines the need for a planned basis for the functioning of society, which has proved its phenomenal and yet unsurpassed effectiveness during the period of industrialization, the creation and development of the education, health, culture, science, the armed forces and other important social institutions in our country. The experience of modern China also proves its effectiveness. It is impossible to ensure the implementation of these functions in the complex by any market or competitive mechanisms. A "market" liberal-monetarist society, as was shown above, is only capable of self - destruction and destruction of the basis of the foundations of society and innovationhuman potential, the creative abilities inherent in it, and the people themselves.

\section{Conclusion}

Stimulating the motivational principles of activating the labor activity of employees is aimed at encouraging employees to increase production, ensuring the resource potential of an active social policy of the state. All sources of income, the amount and direction of income and expenditure of taxes and social contributions should be transparent and understandable to every employee and consumer of public goods.

Coordination of personal, collective and public interests implies, first of all, the creation of mechanisms that exclude the possibility of the emergence and development of a level of socio-economic inequality that is dangerous for the stability of society. 
It is easy to understand that the implementation of these functions involves a significant departure from the purely market principles of the organization of the economy and society as a whole.

\section{Acknowledgments}

None.

\section{Conflicts of interest}

The author declares no conflict of interest.

\section{References}

1. Volgin NA. State and municipal social policy.M KnoRus, 2016.
2. Tavokin E.P. Social Policy: Textbook. 2nd edition, revised and enlarged. Moscow: 2021.

3. Decree of the President of the Russian Federation «On the concept of the transition of the Russian Federation to sustainable development» 1, 1996, No. 440 // Collected Legislation of the Russian Federation. 1996. No. 15. Art. 1572.

4. Yearbook of the United Nations.

5. Constitution of the Russian Federation.

6. Smirnov A.S. Social policy of a large corporation. M., 2005. 